\title{
ANALISA HASIL PENGELASAN BAJA SA333 Grade 6 UNTUK APLIKASI PLTN
}

\author{
Suherman*1, Herbanu Dwi Kuncoro², Ilmi Abdullah², Susri Mizhar ${ }^{3}$, \\ ${ }^{1}$ Program Studi Teknik Mesin, Fakultas Teknik-Universitas Muhammadiyah Sumatera Utara \\ ${ }^{2}$ Jurusan Teknik Mesin Institut- Fakultas Teknologi Industri, Institut Teknologi Medan (ITM) \\ ${ }^{3}$ Program Studi Teknik Mesin, Akademi Teknik Deli Serdang (ATDS)
}

\begin{tabular}{l}
\hline INFORMASI ARTIKEL \\
\hline Riwayat Artikel: \\
Diterima: \\
20 Juni 2020 \\
Diterima dalam bentuk revisi: \\
20 Juli 2020 \\
Disetujui: \\
24 Juli 2020 \\
\end{tabular}

Kata kunci:

SA 333 grade 6

SMAW

Kampuh V

BWR

PLTN

\begin{abstract}
ABSTRAK
ANALISA HASIL PENGELASAN BAJA SA333 Grade 6 UNTUK APLIKASI PLTN. Baja SA333 Gr-6 merupakan baja karbon rendah (C-Mn) yang sering digunakan dalam struktur Pembangkit Listrik Tenaga Nuklir (PLTN) karena memiliki sifat yang menguntungkan seperti konduktivitas termal yang lebih tinggi dan ekspansi termal yang lebih rendah. Baja ini digunakan sebagai pipa utama pengangkutan panas (primary heat transport) untuk reaktor air berpendingin gas (Heavy Water Gas Cooled Reactor, HWGCR) dan pipa pada reactor pressure vessels (RPv) dalam sistem PLTN. Tujuan dari penelitian ini adalah untuk menganalisa kekuatan mekanis pada hasil lasan pada baja SA A333 grade 6 menggunakan metode SMAW. Baja yang telah dilas diuji merusak (uji tarik dan bending) dan tidak merusak (mikrostruktur) untuk mengetahui kualitas hasil sambungan las. Hasil penelitian ini menunjukkan terjadinya retak pada sambungan las terutama pada permukaan las akibat beban bending. Disimpulkan bahwa baja SA 333 Gr 6 yang dilas dengan metode SMAW belum memenuhi kriteria penerimaan uji menurut ASME IX dan ASME III sehingga belum bisa diterapkan di pembangkit listrik tenaga nuklir.
\end{abstract}

\begin{abstract}
Analysis Weld Metal of SA 333 Grade 6 For Nuclear Power Plants. The SA333 Gr-6 steel is a low carbon steel (C-Mn) that is often used in the structure of nuclear power plants because it has properties such as higher thermal conductivity and lower thermal expansion. There is used as the primary heat transport pipe for Heavy Water Gas-Cooled Reactors (HWGCR) and plates in pressurized vessels. The purpose of this study was to analyze the mechanical strength of the weld joint of SA A333 grade 6 steel using the SMAW method. The weld metal specimen is a destructive test (tensile and bending tests) and non-destructive (microstructure) to determine the quality of the weld joint. The results of this study indicate the presence of cracks in the welded joints, especially on the welding surface due to bending loads. It was concluded that SA $333 \mathrm{Gr}$ 6 steel welded by the SMAW method did not acceptance criteria according to ASME IX and III code so that it could not be applied in nuclear power plants

Keywords: SA 333 grade 6, SMAW, V groove, BWR, nuclear power plant
\end{abstract}

(C) 2020 Jurnal Pengembangan Energi Nuklir. All rights reserved

\section{PENDAHULUAN}

Akhir-akhir ini kebutuhan energy listrik sangat tinggi seiring tumbuhnya banyak industry sehingga menyebabkan seringnya terjadi pemadaman listrik, hal ini terutama terjadi di pulau Sumatera. Pembangkit listrik tenaga Nuklir (PLTN) merupakan salah satu solusi untuk menyediakan kebutuhan energi yang terus meningkat. Ada beberapa Faktor yang sangat penting pada PLTN yakni desain keselamatan, faktor manusia, penerapan kehandalan safety integrated level (SIL), falsafah gagal aman (fail safe), persyaratan operator dan pengembangan teknologi pengendalian dan pengawasan secara otomatis

*Penulis korespondensi.

E-mail: suherman.me.umsu@gmail.com
[13]. Faktor keamanan yang tinggi bertujuan agar tidak terjadi kebocoran pada reaktor serta fasilitas pendukung lainnya terutama sekali akibat kegagalan material yang digunakan terutama pada sambungan lasnya. Oleh karena itu pada sambungan pipa yang digunakan dalam sistem PLTN harus baik sehingga bisa memenuhi tingkat keamanan yang mengacu pada standar keamanan material untuk PLTN dari American Institute of Steel Construction (AISC). Dalam sistem pembangkit listrik tenaga nuklir banyak jenis baja yang digunakan untuk seperti pada pipa primary heat transport system pada Reactor Pressure Vessel (RPV), Boiling Water Reactor (BWR), Pressurized heavy water reactors 
(PWHR) [12]. Akan tetapi hampir tidak ada Industri baja yang ada di Indonesia yang mampu untuk memproduksi baja untuk reactor nuklir dan bejana tekan pada pembangkit listrik tenaga nuklir karena belum bisa memenuhi spesifikasi, grade dan standar [16].

Meskipun baja tuang baja tahan karat tipe austenitik telah digunakan untuk pipa pendingin utama dari PWR dan pipa sirkulasi ulang di BWR, baja karbon dan Low Alloys Steels (LAS) masih digunakan untuk banyak komponen perpipaan di kedua sistem. Baja Karbon dan LAS sering digunakan karena kombinasi mereka yang relatif murah, sifat mekanik yang baik, kemampuan las yang baik, dan umumnya memiliki ketahanan yang tinggi terhadap stress corrosion cracking (SCC) [18] [22]. Dalam banyak kasus, baja karbon dan baja paduan rendah (Low Alloy Steels) yang dibalut dengan lapisan las permukaan dibasahi pada bagian dalam dengan bahan tahan korosi, seperti baja tahan karat austenitik atau paduan berbasis nikel [22].

Pada sistem pipa pendingin reaktor nuklir baja karbon dan baja paduan rendah banyak digunakan sebagai contoh, baja karbon SA-516 grade 70 untuk perpipaan PWR, sedangkan SA-106 grade $\mathrm{B}$, dan SA-333 grade 6 untuk pipa steam dan pipa air pengumpan (feedwater piping) pada BWR [22].

Baja SA333 Gr-6 merupakan baja paduan rendah yang sering digunakan dalam struktur pipa pengumpan air pada BWR karena mempunyai sifat yang menguntungkan seperti konduktivitas termal yang lebih tinggi dan ekspansi termal yang lebih rendah. Baja ini digunakan sebagai sistem pipa pengangkutan untuk reaktor air berpendingin gas (Heavy Water Gas Cooled Reactor, HWGCR) dalam sistem PLTN [3] dan pipa ini juga digunakan pada pipa penyalur minyak dan gas untuk aplikasi bertemperatur rendah karena memiliki ketangguhan pada temperature rendah [1]. Kekuatan tarik meningkat dengan semakin menurunnya temperatur uji hingga $-150{ }^{\circ} \mathrm{C}$ akan tetapi membentuk patahan getas [26]. Pemilihan baja ini sebagai bahan untuk struktur reaktor didasarkan pada biaya rendah, kemudahan pembuatan, koefisien ekspansi termal yang rendah yang memberikan ketahanan kelelahan termal dan juga menghambat perkembangan tegangan sisa, dan ketangguhan yang lebih baik [12].

Baja ini juga sering digunakan pada pipa Primary Heat Transport (PHT) suhu hingga $300{ }^{\circ} \mathrm{C}$ dan tekanan operasi hingga $10 \mathrm{MPa}$ sehingga harus dirancang tahan terhadap kegagalan pada suhu tinggi [19]. Perilaku deformasi berulang pada suhu tinggi pada baja SA 333 grade 6 dimana terjadi peningkatan rata-rata tegangan dan amplitudo tegangan, regangan ratcheting, dan amplitudo regangan plastis meningkat, sedangkan umur ratcheting berkurang. Dengan peningkatan suhu, umur ratcheting meningkat dan akumulasi regangan berkurang hingga $300{ }^{\circ} \mathrm{C}$, sedangkan pada kenaikan suhu lebih lanjut, akumulasi regangan meningkat dengan berkurangnya umur ratcheting. Tingkat ratcheting minimum diamati pada temperature $250{ }^{\circ} \mathrm{C}$ dan $300{ }^{\circ} \mathrm{C}$. Fenomena dynamic strain aging (DSA) menyebabkan pengerasan material. Jenis kegagalan pada suhu diatas $250{ }^{\circ} \mathrm{C}$ berupa retak yang memotong batas butir (transgranular), sedangkan pada $350{ }^{\circ} \mathrm{C}$ bersifat patah ulet [9]. Diatas temperature $250{ }^{\circ} \mathrm{C}$ umur fatik berkurang seiring temperaturnya meningkat akibat efek DSA [24].

Penelitian pengelasan pada baja SA 333 grade 6 tidak banyak dilakukan oleh peneliti, kombinasi pengelasan GTAW dan SMAW telah dilaporkan oleh [12][5]. Analisa lebar weld bead terhadap nilai kekerasan Vickers pada baja SA A333 grade B telah diteliti oleh Ardiansyah [5]. Pengelasan dilakukan dengan kombinasi metode GTAW dan SMAW dengan 4 layer dimana lebar bead berpengaruh terhadap nilai kekerasan, semakin tinggi lebar weld bead makin nilai kekerasan juga akan semakin meningkat. Pemberian perlakuan termal aging pada baja paduan tinggi setelah pengelasan GTAW memberikan efek peningkatan kekuatan tarik dan umur lelah [25].

Tujuan dari penelitian ini adalah untuk menganalisa kelayakan dari sebuah sambungan dengan menggunakan metode pengelasan SMAW pada baja SA 333 grade 6 yang digunakan untuk pipa BWR pada sebagai komponen utama pembangkit listrik tenaga nuklir (PLTN) yang akan dibangun di Indonesia. 


\section{POKOK BAHASAN}

Ada enam jenis reaktor nuklir yang saat ini digunakan untuk operasi komersial yaitu Light-water cooled reactors yang terdiri dari Boiling light water reactor (BWR), Light water cooled, graphite-moderated reactor ( $L W G R$ ), Pressurized light water reactor (PWR), sedangkan jenis lain adalah Pressurized heavy water reactor (PHWR), Gas-cooled reactor (GCR), dan Fast breeder reactor (FBR) [23].

Pada pembangkit listrik tenaga nuklir jenis Boiling Water Reactor (BWR) adalah teknologi paling luas kedua digunakan yaitu sekitar 18\% diseluruh negara-negara yang menggunakan energy nuklir. Demikian pula untuk PWR, menggunakan jenis bahan bakar dan air ringan yang sama sebagai pendingin dan moderator. Perbedaan utama dari teknologi BWR adalah bahwa hanya ada satu siklus air yang sama digunakan sebagai media pendingin, moderator dan kerja dalam siklus turbin uap. BWR terdiri dari reaktor, yang mengakomodasi batang bahan bakar. Air dipompa melalui bejana dan menyerap panas, yang dilepaskan diinti reaktor selama reaksi fisi nuklir. Sementara air dijaga di bawah tekanan rendah sekitar 7 $\mathrm{MPa}$, hal itu akan mendidih di inti pada sekitar $290{ }^{\circ} \mathrm{C}$ sehingga itulah sebabnya disebut reaktor air mendidih. Uap kemudian diumpankan langsung ke turbin uap, sehingga cairan pendingin juga berfungsi sebagai fluida kerja (Gambar 1) [23].

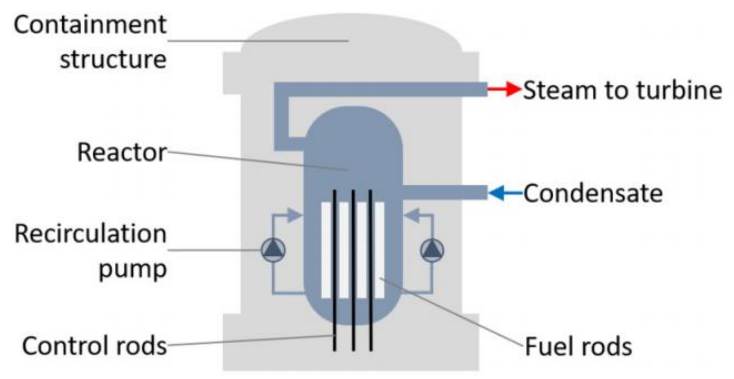

Gambar 1. Skematik diagram dari BWR [23].

Banyak proses pembuatan struktur pembangkit listrik tenaga nuklir terutama berbahan baja paduan rendah harus dilakukan proses penyambungan logam dengan cara pengelasan. Pengelasan adalah suatu proses penyambungan kedua logam dengan menggunakan panas dan atau tanpa tekanan. Ada beberapa jenis proses penyambungan logam yang sering digunakan dalam penyambungan pipa pada instalasi PLTN yaitu dengan proses pengelasan jenis GTAW, GMAW, FCAW, SMAW. Sedangkan pada pelat baja paduan rendah dilakukan proses penyambungan dengan metode electroslag welding dan Submerged Arc welding (SAW) [22].

Pengelasan metode Shielded Metal Arc Welding (SMAW) adalah suatu jenis pengelasan yang menggunakan busur listrik untuk mencairkan elektroda las. Proses pengelasan SMAW cocok untuk sebagian besar logam ferro dan nonferrous, dengan berbagai ketebalan. Metode ini dapat digunakan di semua posisi dan relatif ekonomis akan tetapi kualitas lasan ini tergantung terutama pada keterampilan tukang las [17].

Posisi sambungan las tumpul (but joint) dekat elbow pada pipa BWR baja SA 333 grade 6 seperti pada gambar 2 (lingkaran merah) dibawah.

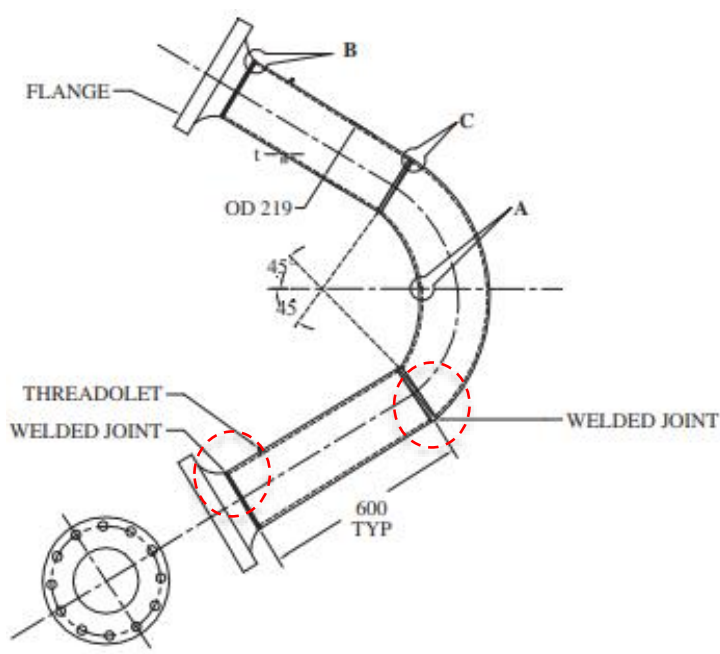

Gambar 2. Sambung las pada pipa BWR [20, 21].

Proses pengelasan untuk bejana bertekanan biasanya menggunakan elektroda las jenis E7018 dimana termasuk jenis basic. Jenis elektroda ini mengandung lapisan kalsium karbonat tinggi (batu kapur) dan kalsium fluoride (Fluorspar), membuat lapisan terak lebih banyak cairan dari pada pelapis rutile. Hal ini juga akan membuat pembekuan cepat yang membantu pengelasan diposisi vertikal dan overhead. Elektroda ini digunakan untuk pengelasan bagian-bagian fabrikasi menengah dan berat dimana kualitas las lebih tinggi, sifat mekanik yang baik dan ketahanan 
terhadap retak karena diperlukan regangan tinggi [17].

Untuk mengetahui kualitas sambungan las maka sesuai standar ASME section IX test coupon berupa pipa baja dilakukan proses pengujian merusak (destructive test) seperti pengujian tarik, pengujian lengkung dan pengujian kekerasan. Untuk menghitung kekuatan tarik pada baja yang telah dilas menggunakan persamaan 1.[17]:

$$
\sigma=\frac{F}{A}(M p a)
$$

\section{Dengan,}

$\sigma$ adalah kekuatan tarik maksimum, $\mathrm{F}$ adalah gaya untuk mematahkan specimen uji dan $\mathrm{A}$ adalah luas penampang.

Kekerasan pada daerah las, Haz dan Logam induk dapat dihitung dengan persamaan 2.[17]:

$$
H v=1,854 \frac{F}{d^{2}}
$$

\section{Dengan,}

Hv adalah nilai kekerasan Vickers, $\mathrm{F}$ adalah beban identor dan d adalah diagonal bekas injakan

Pengujian lengkung (bend) dilakukan pada bagian akar las (root) dan permukaan las (face) dengan tujuan untuk mengetahui kekuatan lengkung pada daerah las. Pengujian ini merupakan kualitatif dimana hasil penelitian didapatkan berdasarkan kriteria penerimaan sesuai standar ASME section IX.

Selain itu pengujian komposisi kimia dilakukan sebagai dasar untuk menghitung karbon ekuivalen. Menurut Kou [8] untuk Baja $\mathrm{C}-\mathrm{Mn}$ dengan kandungan $\mathrm{Mn}$ dan $\mathrm{Ni}$ yang tinggi karbon equivalen dapat dihitung dengan persamaan 3

$C E=C \frac{M n}{6}+\frac{N i}{15}+\frac{C r}{5}+\frac{C u}{13}+\frac{M o}{4}$

Dengan,

$\mathrm{CE}$ adalah karbon equivalen

\section{METODE PENELITIAN}

Material yang digunakan pada penelitian ini adalah pipa baja SA 333 grade $6(\mathrm{C}-\mathrm{Mn})$ dengan diameter luar $88,9 \mathrm{~mm}$, ketebalan 8 $\mathrm{mm}$ dan panjang $200 \mathrm{~mm}$. Adapun parameter pengelasan yang dilakukan pada penelitian ini seperti pada tabel (1).

Tabel 1. Parameter pengelasan baja SA 333 gr 6

\begin{tabular}{ll}
\hline Parameter pengelasan & \\
\hline Polaritas & DCEP \\
Kuat arus & $90 \mathrm{~A}$ \\
Jenis elektroda & E7018 \\
Posisi pengelasan & $6 \mathrm{G}$ \\
Kecepatan pengelasan & $75-110 \mathrm{~mm} / \mathrm{s}$ \\
\hline
\end{tabular}

Pengujian komposisi kimia dari baja yang digunakan menggunakan spectrometer analisis dengan komposisi yaitu C: 0,328; Si: 0,227; Mn: 1,84; P: 0,022; S: 0,011; Cr: 0,098; Mo: 0,094; Ni: 1,98; Al: 0,015; Cu: 0,071; V: 0,211; W: 0,048; Pb: 0,027. Pipa baja pada kedua ujungnya dibuat kampuh single $V$ dengan sudut $30^{\circ}$ dan jarak celah (gape) $3 \mathrm{~mm}$ untuk membuat test coupon.

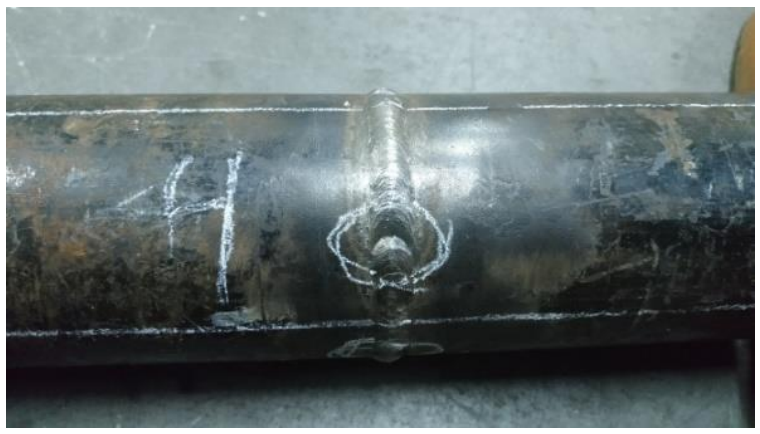

Gambar 3. Test coupon Pipa Baja SA 333.

Pengamatan secara visual hasil pengelasan mengacu kepada standar ASME IX (QW 194) [4]. Pipa yang telah dilas selanjutnya dilakukan pengujian secara visual menggunakan welding gage (gambar 3). Dalam mengambil specimen uji mengacu kepada standar ASTM section IX sebagaimana pada gambar (4).

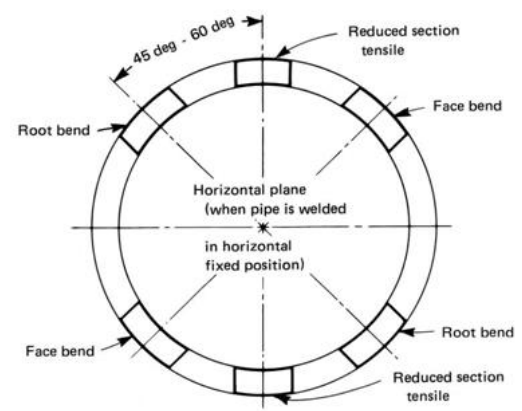

Gambar 4. Pengambilan specimen uji. 
Pengujian tarik dan uji lengkung dilakukan dengan menggunakan mesin hidrolik (gambar 5.b). Specimen uji tarik mengacu kepada standar ASME IX (QW 463.1d).

Pada pengujian lengkung (bend test) dilakukan pada daerah permukaan (face) dan daerah akar (root) las masing-masing 2 buah (gambar 5.a). Diameter jig yang digunakan pada pengujian lengkung merupakan perbandingan antara ketebalan specimen uji yang mengacu kepada standar ASME IX QW 466.1. Pengujian kekerasan dilakukan pada penampang melintang sepanjang $20 \mathrm{~mm}$ dengan mesin uji kekerasan metode micro Vickers dengan beban 1000gram pada logam induk, daerah Haz dan logam las dan identasi dilakukan dengan masing-masing jarak antar identasi $0,5 \mathrm{~mm}$. Pengamatan struktur mikro pada daerah las, haz dan logam induk menggunakan mikroskop optic metalurgi yang sebelumnya dilakukan proses grinding, polishing dan etsa pada specimen uji (larutan $\mathrm{HNO}_{3}+$ alkohol).
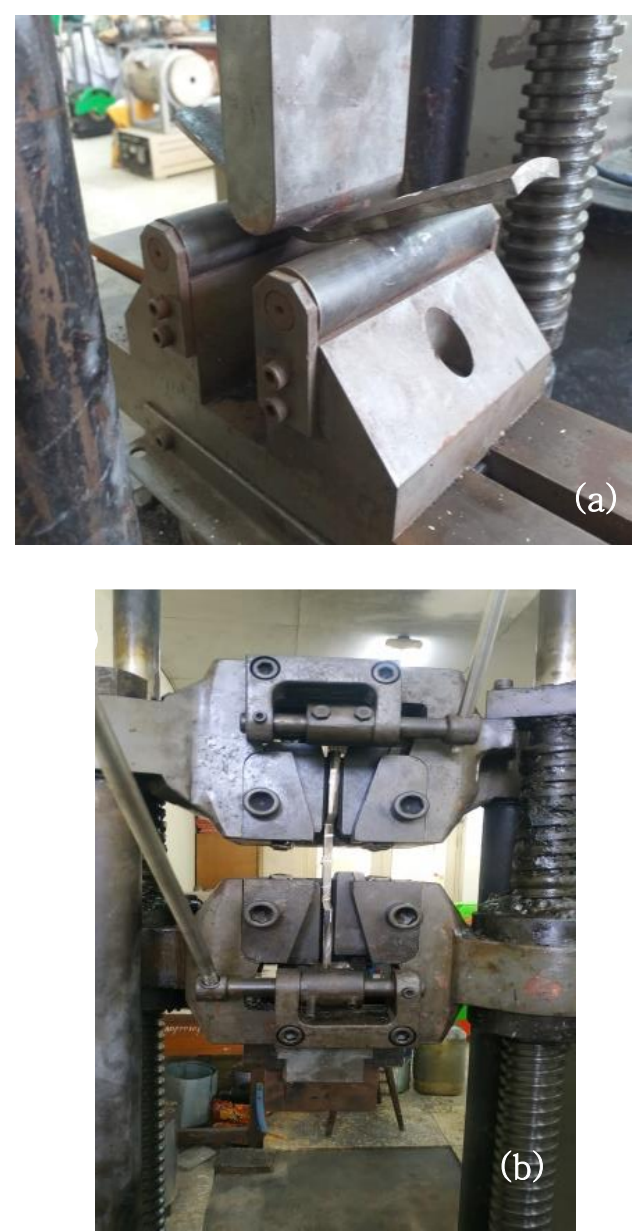

Gambar 5 a) pengujian lengkung (bend test) dan b) uji Tarik (tensile test).

\section{HASIL DAN PEMBAHASAN}

Baja baja SA 333 grade 6 dapat diklasifikasikan termasuk baja paduan rendah karena mempunyai kandungan paduan rendah [3,22]. Dari persamaan 3 diatas didapat nilai sebesar karbon ekuivalen sebesar 0,815. Kandungan Mn yang cukup besar akan membentuk mangan sulfide (MnS) yang sangat efektif menghilangkan hot shortness, unsur Mangan juga berfungsi sebagai penstabil austenite terutama pada temperature rendah menghindari transformasi ke fasa martensit [10]. Sedangkan penambahan Ni pada baja memberi pengaruh terhadap kemampu kerasan dan meningkatkan ketangguhan baja. Akan tetapi kandungan $\mathrm{Mn}$ dan $\mathrm{Ni}$ yang cukup besar pada baja memberikan efek meningkatnya sensifitas irradiasi [22].

\subsection{Struktur Mikro}

Pengamatan mikrostruktur dari baja logam induk dan setelah proses pengelasan baja SA 333 grade 6 ditunjukkan (gambar 6). Mikrostruktur dari logam induk terdiri dari fasa ferit (warna putih) dan perlit (warna hitam), sebagian besar didominasi oleh struktur fasa ferit [7] dengan ukuran butir ferit 20-30 $\mu \mathrm{m}$ sedangkan fase perlit berukuran 10-20 $\mu \mathrm{m}$ (gambar 6.a). 

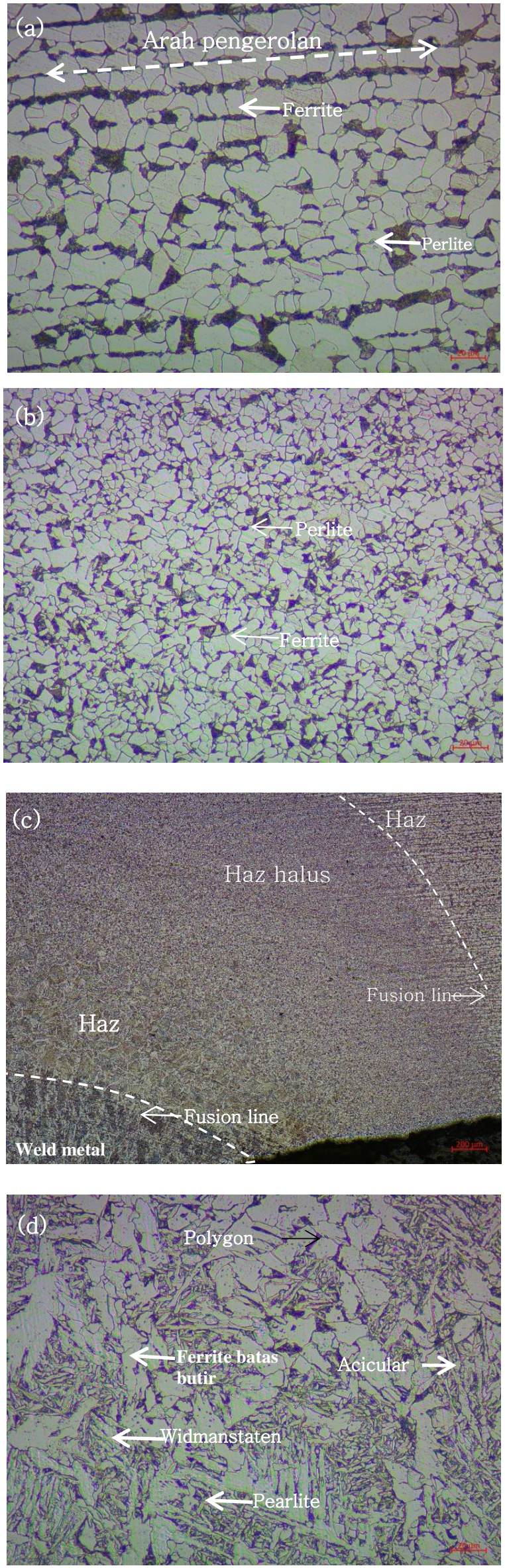

Gambar 6. photo mikro baja SA 333 a) material induk, b) Haz halus, c) daerah fusi dan d) Logam Las.
Panas yang dibutuhkan untuk proses penyambungan logam mempengaruhi logam pada sebelah sisi daerah fusi (fusion zone) sehingga mempengaruhi struktur mikro logam yang biasanya disebut daerah terpengaruh panas (heat affected zone). Mikrostruktur pada daerah Haz sebagaimana ditunjukkan pada (gambar 6b), ukuran butir ferit dan perlit mengalami perubahan ukuran menjadi lebih kecil dengan ukuran kira-kira 10-20 $\mu \mathrm{m}$.

Pada daerah HAZ dibagi lagi menjadi dua wilayah, zona sebagian meleleh (Partial Melting Zone) dan zona yang terkena dampak panas "T-HAZ". Zona sebagian meleleh (PMZ) tetap ada di semua lasan fusi dalam paduan baja karena transisi dari $100 \%$ cair ke $100 \%$ padat terjadi pada batas fusi. Selain itu, mekanisme lain yang menghasilkan pencairan lokal diwilayah yang sempit di sekitar zona fusi. Hal ini termasuk peleburan batas butir karena segregasi dan fenomena yang dihasilkan dari pencairan lokal yang terkait dengan partikel penyusunnya. Penunjukan THAZ digunakan untuk membedakan daerah HAZ di mana semua reaksi metalurgi terjadi dalam keadaan padat, yaitu, tidak ada pencairan terjadi [11].

Garis fusi (fusion line) yang membatasi antara daerah las (weld zone) dan daerah $\mathrm{Haz}$ terlihat jelas pada gambar (6.c). Zona fusi terdiri dari dua daerah, daerah campuran mewakili bagian tersebut dari zona fusi di mana logam dasar dan logam pengisi bercampur. Sekitaran wilayah ini sepanjang batas fusi, mereka didefinisikan suatu wilayah disebut zona tidak berampur (Unmix Zone) [11]. UMZ terdiri dari logam yang dilelehkan dan logam dasar yang membeku kembali tetapi tidak bercampur dengan logam pengisi. Dalam beberapa sistem paduan, UMZ dapat menunjukkan struktur mikro dan sifat yang sangat berbeda dari wilayah campuran, khususnya ketika logam pengisi yang berbeda (gambar 6.c). Struktur mikro dan sifat dari HAZ sepenuhnya dikontrol oleh kondisi termal yang dialami selama pengelasan dan perlakuan panas pasca-las (PWHT) [11].

Gambar (6.d) menunjukkan hasil pengamatan struktur mikro pada logam las (weld metal) dengan mikroskop optik metalurgi, mikrostruktur pada logam las terdiri dari ferit batas butir (grain boundary ferrite), widmanstaten ferit dan acicular ferit [15]. 
Perubahan struktur mikro pada daerah las ini karena ekspansi termal selama pemanasan dan kontraksi selama pendinginan dapat menghasilkan pola tegangan yang kompleks di dalam dan sekitar lasan, tegangan ini selanjutnya dapat mempengaruhi struktur mikro dan sifat-sifat dari lasan [11]. Struktur dendrite berukuran kasar yang terbentuk pada daerah las berupa equaxed dendrite dimana ukuran dendrite arm spacing (DAS) ini sangat dipengaruhi oleh laju pendingin logam cair yang terjadi selama proses pengelasan berlangsung [8]. Dalam pengelasan fusi, proses pembekuan pada kolam las terjadi bersama-sama dengan logam induk. Pembekuan pada zona fusi terjadi tahap demi tahap dan proses pembekuan diatur oleh kecepatan pengelasan dan juga pada antarmuka fasa cair-padat selama pembekuan [6].

Mikrostruktur pada logam las memberikan efek yang signifikan pada sifat mekanik dan sensifitas terhadap radiasi selain itu sangat berpengaruh terhadap laju perambatan retak terutama pada daerah las dan Haz akibat beban internal yang sangat besar [22]. Retak awal berupa cacat las pada logam las akan sangat berbahaya karena laju perambatan retak dipengaruhi beban yang bekerja sepanjang ujung retak dan tumbuh sepanjang batas butir. Semakin besar ukuran besar butir pada daerah las maka akan mempercepat laju pertumbuhan perambatan retak.

\subsection{Kekerasan}

Gambar (7) menunjukkan nilai kekerasan baja SA A333 Grade 6 pada daerah las, Haz dan Logam Induk. Nilai kekerasan Vickers untuk semua daerah hampir memiliki nilai kekerasan yang tidak terlalu berbeda. Nilai kekerasan pada daerah logam induk kira-kira $160 \mathrm{Hv}$ dan sedikit mengalami sedikit penurunan nilai kekerasan pada daerah las dan Haz. Tingkat pendinginan lokal memiliki pengaruh signifikan pada ukuran (atau skala) dari struktur pemadatan yang terbentuk, dengan nilai Gradien temperature dan laju pertumbuhan pembekuan logam yang tinggi menghasilkan struktur yang sangat halus [11].

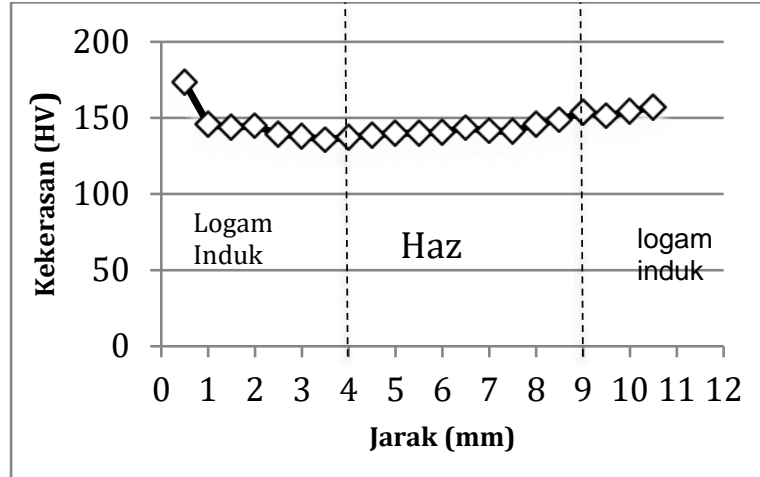

Gambar 7. Nilai kekerasan Baja SA 333 Grade 6.

\subsection{Kekuatan Tarik dan Lengkung Lasan}

Kekuatan tarik dan kekuatan lengkung dari lasan baja SA333 grade 6 sebagaimana ditunjukkan pada tabel (2). Nilai kekuatan tarik maksimum sebesar $435 \mathrm{MPa}$ [2]. Nilai kekuatan tarik meningkat dibanding material induk. Specimen uji tarik mengalami patah pada logam induk setelah pengujian, hal ini menunjukkan kekuatan sambungan cukup baik menerima beban tarik. Dalam hal ini sudah memenuhi kriteria penerimaan terhadap beban tarik.

Pengujian lengkung (bend test) pada daerah las dilakukan masing-masing pada daerah root dan face sebanyak 2 spesimen uji. Specimen uji mengalami patah getas hal ini karena terjadi cacat lasan yaitu lack of root fusion dan lack of sidewall fusion sehinga specimen uji tidak mampu menahan beban lengkung. Sedangkan pada specimen face bend tidak mengalami kerusakan untuk kedua specimen uji.

Pada penerapan dilapangan, pipa BWH menerima tekanan internal hingga $10 \mathrm{MPa}$ sehingga harus bebas dari cacat las sehingga ketika menerima beban lengkung tidak boleh mengalami retak. Adanya cacat berupa void pada dinding las dan akar las akibat ketidaksempurnaan lasan merupakan daerah yang paling lemah terhadap beban internal dari dalam pipa BWR sehingga dimungkinkan menjadi inisiasi retak awal. Retak ini akan tumbuh dan berkembang secara cepat akibat beban internal (internal pressure) dan akan menyebabkan kegagalan pada struktur sambungan las pipa [21].

Adanya retak berukuran kecil pada pada daerah las akan menyebabkan pecahnya sambungan pada pipa Baja SA 333 grade B yang digunakan sebagai sistem pipa 
pengangkutan untuk reaktor air berpendingin gas (Heavy Water Gas Cooled Reactor, $H W G C R)$ dalam sistem PLTN sehingga menyebabkan terganggunya sistem pendingin dan hal ini memicu kenaikan temperatur secara cepat yang berakibat terjadinya kerusakan pada selongsong reactor sehingga bisa terjadinya pelepasan material radioaktif dari bahan bakar. Meskipun reaktor sudah dimatikan akibat kegagalan pada sistem pendingin, produksi fisi akan terus berjalan sehingga menyebabkan panas yang berlebih dari reaktor [27].

Tabel 2. Sifat mekanis baja SA 333 Grade 6

\begin{tabular}{llll}
\hline \multirow{2}{*}{ Spesiemen } & $\begin{array}{l}\text { Kekuatan } \\
\text { Tarik } \\
\text { Maks } \\
\text { (MPa) }\end{array}$ & \multicolumn{2}{c}{$\begin{array}{l}\text { Uji lengkung } \\
\text { (Bend) }\end{array}$} \\
\cline { 3 - 5 } & Root & Face \\
\hline Logam induk & 435 & - & - \\
\hline Specimen 1 & 608 & Patah & Baik \\
\hline Specimen 2 & 570 & Patah & Baik \\
\hline
\end{tabular}

Agar terhindar dari cacat las seperti slag yang terjebak dalam kolam las dan menghindari retak las pada saat proses fabrikasi pembuatan $\mathrm{RPv}$ maka diperlukan pemanasan awal (preheat) dan perlakuan panas pasca pengelasan (post weld heat treatment) [22], proses perlakuan panas pasca pengelasan ini sangat signifikan mengurangi laju pertumbuhan perambatan retak (fatigue crack growth rate) pada pipa baja yang dilas [12].

\section{KESIMPULAN}

Baja SA 333 grade 6 merupakan baja paduan rendah yang selalu digunakan pada pipa pengumpan air pada boiling water reactor $(B W R)$, pipa untuk reaktor pendingin gas (heavy water gas cooled reactor), pipa primary heat transport (PHT) dari Pressurized Heavy Water Reactors (PWHR). Dalam proses assembling komponen utama diatas harus dilakukan proses penyambungan dengan teknik pengelasan. Pada penelitian ini dilakukan pengelasan pada pipa SA 333 grade 6 dengan menggunakan metode SMAW tanpa pemanasan awal sebelum pengelasan dan pasca pengelasan. Proses pengelasan ini belum memenuhi kriteria penerimaan (acceptance criteria) menurut standar ASME IX dan ASME III karena masih terjadi kerusakan berupa retak pada bagian akar las ketika menerima beban lengkung sehingga belum bisa diterapkan di fasilias pembangkit listrik tenaga nuklir.

\section{SARAN/ REKOMENDASI}

Untuk mendapatkan sifat fisis dan mekanis dari sambungan las pada baja SA 333 grade 6 yang memenuhi standar kriteria ASME IX dan ASME III maka perlu diteliti lebih lanjut dengan melakukan kombinasi metode pengelasan GTAW dan SMAW dengan melakukan beberapa parameter penelitian seperti kecepatan pengelasan, besar masukan panas, jenis elektroda las dan perlakuan panas sebelum pengelasan (preheat) dan perlakuan panas pasca pengelasan (post weld heat treatment) untuk mendapatkan kualitas sambungan las yang memenuhi standar sehingga layak untuk digunakan dalam fasilitas pembangkit listrik tenaga nuklir.

\section{DAFTAR ACUAN}

[1]. ASME B31.5-2001, 1992, Refrigeration Piping and Heat Transfer Components, New York USA

[2]. ASTM, 2004, Standard Specification for Seamless and Welded Steel Pipe for Low-Temperature Service

[3]. ASME II, 2017 ASME Boiler and Pressure Vessel code, Part A Ferrous Material Specifications (Beginning to SA-450)

[4]. ASME IX, 2017 ASME Boiler and Pressure Vessel code, Qualification Standard for welding, brazing, and Fusing Procedures: Welders: Brazers; and Welding, Brazing, and Fusing Operators.

[5]. Ardiansyah, M., 2019, Analisa Lebar Weld Bead Pada Pipa Carbon Material SA333 Grade 6 Dengan Proses GTAW+SMAW Terhadap Kekerasan, Struktur Mikro, dan Radiography, Tugas Akhir Program Studi D4 Teknik Pengelasan Jurusan Teknik Bangunan Kapal Politeknik Perkapalan Negeri Surabaya, Surabaya

[6]. Granjon, H., 2002, Fundamentals of welding metallurgy, Abington Publishing, Cambride England

[7]. Kamat, S.V., Srinivas, M., and Rao, P.R., 2011, Effect of temperature on the mode I and mixed mode I/III fracture toughness of SA333 steel, Materials Science and Engineering A, p 4141-4146

[8]. Kou, S, 2003, Welding Metallurgy, Second Edition, Publisher Jhon Wiley \& Sons, New York

[9]. Kumar, G and Kumar, A., 2019, Asymmetric cyclic deformation behavior of SA 333 steel at elevated 
temperatures, World Journal of Engineering Volume $16 \cdot$ Number $1,78-86$

[10]. Lippold, J.C, and Kotechi, D.C., 2005, Welding metallurgy and Weldability of Stainless Steel, Publisher Jhon Wiley \& Sons, New York

[11]. Lippold, J.C, 2015, Welding metallurgy and weldability, Publisher John Wiley and Sons

[12]. P. K. Singh, K. K. Vazeand H. S. Kushwaha, 2002, Characterisation Of Girth Pipe Weld for Primary Heat Transport System of Pressurised Heavy Water Reactors, Bhabha Atomic Research Centre Mumbai, India

[13]. Arindya, R., 2019, Studi Keselamatan Pembangkit Listrik Tenaga Nuklir, Seminar Nasional sinergi (Energi dan Teknologi), Jurnal Unisma Bekasi

[14]. Singh PK, Chattopadyay J, Khuswaha HS, 1997, Tensile and fracture properties of primary heat transport system piping material. Technical Report: BARC/1997/E/108, Bhabha Atomic Research Centre, Mumbai.

[15]. Suherman, Muliadi, D. Ridho, M.S., dan Marpaung, C.P, 2018, Pengaruh Kuat Arus Terhadap Sifat Mekanis Dan Struktur Mikro Sambungan Las SMAW Baja SA 516 GR.70, Jurnal Mekanik Jurusan Teknik Mesin ITM, Vol 4 nomor 2.

[16]. Dewi, D, Lumbanraja, S.M., 2017, Rantai Pasok Industri Baja untuk Pembangunan PLTN di Indonesia, Jurnal Pengembangan Energi Nuklir, Vol. 19, No. 1, 51-60

[17]. TWI, 2018, CSWIP Welding Inspector WIS 5, Cambridge UK

[18]. B.M. Gordon and G.M. Gordon, 1987, Materials Aspects Of BWR Plant Life Extension, Nuclear Engineering and Design, North-Holland, Amsterdam

[19]. R. Rastogi, V.Bhasin, K.K. Vaze, H.S. Kushwaha, 2002, Assessment of integrity of components in piping of 500 MWe PHWR: using R-6 method, Nuclear Engineering and Design 212, pp 99-108

[20]. P. Gandhi, M. Saravanan, S. Vishnuvardhan, D.M. Pukazhendhi, G. Raghava, M.K. Sahu, J. Chattopadhyay, B.K. Dutta, K.K. Vaze, 2012, Experimental fracture studies on carbon steel elbows with and without internal pressure, International Journal of Pressure Vessels and Piping, 111-112.

[21]. M. Saravanan, S. Vishnuvardhan, P. Gandhi a, D.M. Pukazhendhi, G. Raghava, M.K. Sahu, J. Chattopadhyay, B.K. Dutta, 2016, Fracture studies on carbon steel elbows having part-through notch with and without internal pressure, International Journal of Pressure Vessels and Piping, pp 19-30

[22]. T. Williams and R. Nanstad, 2019, Structural Alloys For Nuclear energy Applications, Chapter Ten, Elsevier publisher

[23]. N, Belyakov, 2020, Sustainable Power Generation, Elsevier Publisher, Chapter Twelve

[24]. K.G. Samuela, V. Ganesana, K.B. Sankara Rao, S.L. Mannana , H.S. Kushwahab, 2004, Strain controlled LCF behaviour of SA-333 Gr 6 piping material in the range 298-673 K, International Journal of Pressure Vessels and Piping 81, pp 973-981.

[25]. W. Yu, M. Fan, W. Jia, F. Xueb , M. Yub , H. Liu, X. Chen, 2019, Thermal aging effect on the tensile and fatigue properties of the narrow-gap TIG welded joints in offshore floating nuclear power plants, International Journal of Fatigue 126, pp 143-154.

[26]. P.C. Chakraborti, A. Kundu, B.K. Dutta, 2014, Weibull analysis of low temperature fracture stress data of 20MnMoNi55 and SA333 (Grade 6) steels, Materials Science \& Engineering A 594, pp 89-97

[27]. Arindya, R, 2017, Studi Keselamatan Pembangkit Listrik Tenaga Nuklir, Prosiding Seminar Nasional Energi dan Teknologi (Sinergi), UNISMA Bekasi. 